\title{
A. D. LINDSAY AND THE PROBLEMS OF MASS DEMOCRACY
}

\author{
Harry A. Holloway \\ University of Oklahoma
}

$\mathrm{T}$

HE LATE A. D. LINDSAY, eminent British socialist, Labour peer, and for many years Master of Balliol College, was once described by Ernest Barker as a "Puritan prophet of democracy." 1 David Easton, on the other hand, charged him with being an "historicist" whose theory served chiefly to explain the past and said little about the present. ${ }^{2}$ An anonymous English reviewer argued that Lindsay presented an incomplete theory that in some respects bore comparison with England's "strictly aristocratic regime of the eighteenth century." " 3 Yet W. Y. Elliott ranked Lindsay's theory among the few classic attempts in modern times to state the case for liberty and equality, and thought his achievement in relating the "operative ideals" of democracy to the Industrial Revolution and the rise of nationalism to be outstanding. ${ }^{4}$

These contrasting views suggest the need for further analysis of Lindsay's theory. There are two related purposes. One is to suggest that the reason for these various interpretations arises from a basic deficiency in the theory itself: the theory is unfinished and ends in ambiguity. This ambiguity, it will be argued, was due to Lindsay's somewhat Hegelian idealism that predisposed him to a critical evaluation of modern industrialism and mass democracy. Given his pessimistic attitude toward these fundamental trends plus his own romanticized view of early democracy in simpler societies, he found it difficult to look hopefully upon modern large-scale and industrialized democracies. In particular he found it difficult to envisage how the "mass man" from whom democratic controls must basically stem could form the popular foundation of the modern state. He promised a second volume to follow his major work, The Modern Democratic State, to deal with "democratic controls"; but it never appeared, though he lived almost a decade thereafter.

In tracking down this key difficulty in Lindsay's theory a second related purpose will be served, that is, the partial testing of a theory of democracy. One of the common criticisms today leveled at the traditional treatment of political theory is its historicism. Theory is treated primarily as an aspect of the past with, at best, secondary concern for the present. However, more than Easton allows, Lindsay did develop a theory, even if "unfinished," of modern democracy. His trouble stems less from his method than from certain conceptions of modern realities that he could not adapt his theory to meet. Lindsay was indeed passing judgment on the present-day

\footnotetext{
'Ernest Barker, "A Philosopher of Democracy," Spectator, 170 (February 26, 1943), 200. Times (London), March 19, 1952, p. 6, contains an obituary that summarizes Lindsay's life.

${ }^{2}$ David Easton, The Political System (New York: Knopf, 1953), p. 259.

" "Democracy Restated," Times Literary Supplement, 42 (February 27, 1943), 98.

'Preface to the American edition of Lindsay's The Modern Democratic State, Vol. 1 (New York: Oxford University Press, 1947). Hereafter this book is referred to simply as $M D S$.
} 
world and incorporating these judgments in his theory, and in this regard escapes much of the weakness behaviorists charge against the more traditional political theory. For this reason he offers a valuable example of theory that can be tested in some degree by reference to recent studies of the actual behavior of modern man.

To claim to test such a theory and one which is "normative" raises a further question. For this Puritan prophet of democracy generalized about and passed judgment upon whole historical periods. Testing such a theory, therefore, can hardly mean offering any final or conclusive proof or disproof of his statements. Still, one may examine an author's assumptions and the coherence and completeness of his theory. One may also question the evidence adduced, point to conflicting evidence, and suggest further lines of inquiry to validate or invalidate the conclusions offered. Further, it is possible to suggest the relevance of the evidence offered to the norms proposed and the possible need for revised norms. The exact relation of norms to questions of fact and logic is hardly within the scope of this paper; but that there is ample precedent for the relating of norms to behavioral studies is well established in the literature of recent political science and sociology. ${ }^{5}$ The purposes of this analysis will therefore be to point out the weakness of Lindsay's theory that led to conflicting estimates, and to test his theory and its assumptions against some conflicting evidence. The conclusion will be that important elements of this idealist's norms are in need of revision to meet the requirements for democracy under modern conditions. In the words of E. H. Carr in analyzing the "new society," Lindsay might be compared with those who look too much behind rather than to "the shore ahead." 6

The examination of Lindsay's theory will proceed first with an analysis of his theory of history and of his closely linked conception of the "modern democratic state" to point up the major difficulty to which his ideas led, specifically the problem of democratic controls. In Lindsay's "synoptic vision" ${ }^{7}$ of history he saw the world divided between two contending forms of individualism, the one idealist and the other materialist. One form was an individualism rooted in an ideal of freedom and man's potentialities for growth and therefore concerned with the dignity and worth of all men. This idealistic view coupled the quest for freedom with an ingrained sense of the good of all, both materially and spiritually. The other form was a secular, atomistic individualism motivated in everything by self-interest and willing to manipulate things or people indifferently in the quest for power and material satisfactions. These two forms of individualism Lindsay called the "Christian" and

\footnotetext{
'Among examples might be cited Bernard Crick, The American Science of Palitics (Berkeley: University of California Press, 1959). The author documents his claim that leading exponents of the scientific or behavioral school have implicitly, if not always overtly, acknowledged and upheld values, particularly the norms of a democratic system. Harold Lasswell, one of those whom Crick cites, has himself written on the subject: "The Normative Impact of the Behavioral Sciences," Ethics, 67 (1957), 1-42. A commonly cited example of the conscious relating of social science to democratic norms is in the study by Berelson et al., Voting (Chicago: University of Chicago Press, 1954), chap. 14. See also the concluding chapters of Campbell et al., The American Voter (New York: Wiley, 1960 ). Additionally, there is Robert E. Dahl's evaluation of models of American democracy in his Preface to Democratic Theory (Chicago: University of Chicago Press, 1956). The work of sociologist Seymour M. Lipset is another good example. See especially the essays published as Political Man (Garden City: Doubleday, 1960).
}

'E. H. Carr, The New Society (London: Macmillan, 1951), p. 5.

'The term is Barker's. See op. cit., p. 200. 
the "scientific"; 8 and it was the clash between these two fundamentally opposed views that he saw manifest in World War II. Democracy and its "Christian" individualism were ranged against a scientific or "economic man" philosophy linked with totalitarianism.

Historically the conflict began in the contrasting views represented by the practice of the democratically governed Puritan congregations, on the one hand, and the authoritarian ideas of Hobbes, on the other. ${ }^{9}$ This latter form of individualism Lindsay further related to a long Utilitarian tradition transmitted after Hobbes by the Benthamites and by Marx's materialist "economic man" philosophy. ${ }^{10}$ In actual application this same materialist and utilitarian philosophy was manifest in the onesided development of science and industry. ${ }^{11}$ The growth of technological powers enabled man to manipulate the material environment as never before; and the quest for the benefits unleashed by this power led to a growing material revolution culminating in the still-continuing Industrial Revolution. But man's self-mastery and hence his mastery of social and political affairs lagged behind his power to manipulate things. "Technical progress means progress in instruments, in the means or power of achieving our ends. ... But when technical progress gets ahead of political and social organization - as since the Industrial Revolution it has - it may so dominate society that it becomes a master instead of a servant. . . " For Lindsay the advance of technology represented by the expanding industrialization of the globe was a "material revolution without a corresponding moral and spiritual revolution." A mounting crisis was thus born that Lindsay saw at a peak in World War II. By the twentieth century industrialization had created soulless, army-like societies in which the mass of men lived routine, mechanical lives dominated by giant organizations and a hierarchy of impersonal managers. ${ }^{12}$ Consequently men were treated as instruments to be manipulated rather than as beings capable of moral and spiritual development.

Still, this system was inherently unstable. The trouble lay not with man's poverty, for the "grim phase" of the Industrial Revolution was over by the beginning of the twentieth century. The trouble went deeper than any economic hardship that remained. For as long as the insatiable quest for self-aggrandizement prevailed, social control fluctuated from one extreme to another: laissez faire anarchy or total planning and control. ${ }^{13}$ Egoistic individuals either rejected restraint and free cooperation altogether or had to be bound together in a scientifically manipulated system. To be free, men had to recognize restraints on themselves and had to be willing to contribute to something beyond their own interests - the common good. Yet the acquisitive economic man philosophy associated with the excessive pace of

${ }^{8}$ A. D. Lindsay, "Christian and Scientific Individualism" Dublin Review, 207 (1940), 185. See also $M D S$, pp. 77-81, in which these are characterized as "Protestant" and "scientific" individualism.

${ }^{\circ} M D S$, pp. 117 and 136ff., respectively. In attaching such signal importance to the Puritans, Lindsay may have been influenced by T. H. Green. See the latter's "Lectures on the English Commonwealth" in his Works (London: Longmans, Green, 1889), Vol. 3.

${ }^{10} M D S$, pp. 84, $140 f f$.

${ }^{11}$ Ibid., pp. 78-81.

12 Ibid., pp. 177-90.

${ }^{13}$ Ibid., p. 144. 
technology threatened this public-spirited outlook. The same materialistic self-seeking that was the inner motivation of totalitarianism and attacked democracy from without threatened to disrupt democracy from within. Nationalism and the workers' movement countered the damaging influence of industrialism in some degree but could not of themselves fully restore the community. ${ }^{14}$ With this generations-old crisis mounting to the possibilities of world-wide devastation by war, the "operative ideals" of democracy needed restatement. How could the democratic state, as the political expression of the value of all human kind, regain control over the forces that threatened to enslave and destroy men? Lindsay wanted to revive and adapt to twentieth-century industrial societies the "spiritual" individualism and democracy of the early Puritan congregations.

On this interpretation of world history and its conflicts, Lindsay's socialism was not to be a secular creed of class war and the abolition of private property. ${ }^{15}$ His socialism was based on idealism, not Marxist materialism. Nor could he believe that an unrestrained competitive individualism naturally produced results beneficial to all without political direction. ${ }^{16}$ Politics had to control economics to insure the dominance of men's better purposes and ideals. The goal was the good society, an ideal of humane and decent living for all. Economically it would be one which insured a national minimum of material well-being to all and restrained the irresponsible power of great economic organizations, if need be by nationalization. ${ }^{17}$ Morally its objective would be to provide an almost mystical sense of fellowship and of belonging. ${ }^{18}$ Lindsay's socialism was a peculiar combination. He contemplated a profound change in the social system eventually but thought in terms of human nature rather than the extension of state controls. He idealized the British labor movement as the embodiment of democratic theory and practice and looked to it to lead present-day society gradually toward the socialist way of life. His socialism was even so moderate that Laski accused him of "failing to face the central issue of property

${ }^{14}$ Ibid., pp. 163-65 and 190-92.

${ }^{15}$ Lindsay did pass through a phase marked by some sympathy for Marxism. But this phase ended by the thirties. See Preface to the 1935 edition of The Essentials of Democracy (London: Oxford University Press, 1951). And in any case his sympathetic treatment of Marx in his Karl Marx's Capital, published in 1925, was such that Adam Ulam later said, "Marx emerges, on the whole . . c curiously similar to Green." See A. B. Ulam, Philosophical Foundations of English Socialism (Cambridge: Harvard University Press, 1951 ), p. 101.

${ }^{16}$ Of Lindsay's attitude towards capitalism Ulam writes, "Capitalism and its theoretical backbone - laissez faire and old liberalism - do not get a hearing before Lindsay." See Ulam, op. cit., p. 102. Lindsay's deep suspicion of the unregulated economy is well conveyed by a remark he once made in praise of Hegel. "Hegel," Lindsay claimed, "is the first political philosopher to acknowledge the independent importance in the State of economic relations and of economic law and yet to show how, while remaining relatively independent, the Economic Community plays its part in the whole and is 'brought back' by the action of the State to serve the general good." See "Hegel the German Idealist" in Social and Political Ideas of Some Representative Thinkers of the Age of Reaction and Reconstruction, ed. F. J. C. Hearnshaw (New York: Barnes \& Noble, 1949), p. 66.

"A. D. Lindsay, "The Philosophy of the British Labour Government" in William Ebenstein, Great Political Thinkers (3rd ed.; New York: Rinehart, 1960), p. 800.

${ }^{18}$ Ibid., p. 805. Ulam describes the "quality pervading the thinking of Lindsay, and of many other theoreticians of the Labour Party" as a "religious semi-mystic one: the citizens of a modern democracy need to be innoculated by what they call the common life." See op. cit., p. 117 . 
and the problems of power to which its relations gives rise." ${ }^{19}$ What Lindsay wanted to change was the acquisitive materialistic motivation that he felt was the basis of capitalism and the prime fault of the social system. The ideal socialist society was one in which men worked, not for their own interests, but for the good of all, and thereby fulfilled their potentialities as individuals. Socialism in this manner he regarded as simply an extension of the older principles of democracy: "the modern democratic state's concern with industrial and economic conditions is but the logical extension of the principle that the state's business is to maintain a system of rights."

Politically the system would be one in which the individual conscience was the "absolute authority." 20 This did not mean that each man had his own way or would even want to, but that the political order recognized the worth and dignity of each man, encouraged him to participate in the common life, and accepted the community as the rightful regulator of the state. For the individual this position brought independent freedom as a democratic citizen; but he also had the responsibility to participate and to form his judgments by reference to the common good, not his own selfish interests. Granted the interdependence of modern societies, men had to be able to work together spontaneously if they were to be free. Otherwise there would be one exteme or the other: anarchy or scientific manipulation and control. In Lindsay's apt phrase, "no amount of manipulation will make a multitude of egoists capable of government." At the base of democracy, therefore, was an assumption, not only of a tradition of freedom, but also a spirit of good will and cooperativeness. The "economic man" of totalitarianism and the aberrations of democracy was not capable of sustained freedom.

Upon these principles Lindsay built his notion of a constitutional democratic state. His most serious difficulty was to explain how individuals organized in the gigantic modern nation could be said to consent to the acts of a large and powerful government, a government which they obviously had no immediate role in assenting to or in directing. Although the answer was complex and, in the end, incomplete, he stated important principles.

In the first place, any democratic system was pluralistic and made up of many voluntary associations based on spontaneous and uncoerced activity. ${ }^{21}$ There was much that democratic citizens did of a private and semi-public nature which the state did not and should not regulate. Furthermore, so far as the state did regulate conduct, it laid down laws which most people willingly obeyed most of the time. Those laws it did enforce and thereby left the citizens no choice to obey had a special urgency as essential to the freedoms of all. ${ }^{22}$ Yet all of these provisions were chiefly negative. They did not explain how individual citizens could be said to participate in and consent to state activity. To meet this problem Lindsay drew upon the idea of the general will. The original form of this concept he drew from the practice of

\footnotetext{
${ }^{19}$ H. J. Laski, "Modern Democracy," Manchester Guardian, March 3, 1943, p. 3.

${ }^{20} M D S$, p. 231.

${ }^{21}$ Ibid., pp. 265-66. Lindsay passed through a phase of pluralism in his intellectual development and was so classified by F. W. Coker in his Recent Political Thought (New York: Appleton-Century, 1934), p. 497.

${ }^{23}$ MDS, pp. $207 f$.
} 
the Puritan congregations, but in application to modern societies he relied upon the form given it by Rousseau and Bernard Bosanquet, especially the latter. ${ }^{23}$

The modern democratic state, Lindsay argued, was governed by a spirit which bound leaders and ordinary citizens in a common will. There was, to begin with, a traditional consensus of values and aspirations developed by national experience as one people. For the "important thing about the successful democratic nation states is ... in their citizens having the same political hopes and aspirations. ..." Added to this consensus, which itself limited what leaders might do and provided a sense of national direction, was the public discussion, with the leaders themselves playing a prominent part, and which created a spirit or sense of what the public wanted..$^{24}$ It was the duty of the leaders chosen by the public to formulate and apply policies in accord with this "will" to make the community "more of a community." ${ }^{25}$ A state guided in this manner could be said to be governed by a general will. There was a consensus to which public discussion added specifics so that the resulting "sense of the community" to a very real degree guided the conduct of statesmen and administrators in the formulation of policies. The conception was one of the "deliberative state" consciously creating social harmony by means of adjustment, discussion, and cooperation. ${ }^{26}$ The "sovereignty" of the general will reconciled the more ultimate sovereignty of the individual conscience with the vast twentieth-century state and its elite of statesmen and administrators.

But Lindsay himself admitted the account of the modern democratic state was not complete. Up to this point he had relied heavily on Bosanquet's idealist theory of the state and felt the need to go beyond. The particular problem was the matter of democratic controls. And it was at this point that the greatest weakness in Lindsay's theory appeared.

Modern societies were enormous by comparison with the early agricultural societies in which democracy seemed a natural way of conducting affairs. Industrialization and its material benefits lured men on to achievements that threatened to overwhelm the seeming master. The cleavage between management and worker was great; and industrialization constantly reinforced an hierarchical and undemocratic form of organization. Concentrations of economic power grew apace and the state was hard put to control not only the industrial obligarchy but also the military forces at its disposal, and the civilian bureaucracy. Life for the great mass of men in this army-like industrial system was routine and mechanical to an extent that

\footnotetext{
"Ibid., pp. 235ff. Some years earlier Lindsay had criticized the concept of the general will in Rousseau and Bosanquet because of its absolutist implications. See his essay "Absolutism" in Encyclopedia of the Social Sciences, 1 (New York, 1930), 381; and also his more extended criticism of Bosanquet, "Bosanquet's Theory of the General Will," Aristotelian Society Supplement, 8 (1928), 31-44.

${ }^{24}$ Lindsay referred briefly (p. 246) to Ernest Barker's then-recent exposition of "government by discussion" in Reflections on Government. Lindsay's idealist terminology perhaps somewhat obscured the importance he attached to discussion. In an earlier exposition of his ideas he gave as the "main thesis of these lectures ... that discussion is fundamental to democracy. ..." The Essentials of Democracy, p. 1. The book appeared originally in 1929.

${ }^{25}$ MDS, pp. $245 \mathrm{ff}$.

${ }^{20}$ John Chapman, Rousseau - Totalitarian or Liberal? (New York: Columbia University Press, 1956), p. 136.
} 
wasted men's souls and frustrated their potentialities for development. The "plain man" to whom democracy gave a share in government by granting him the vote and liberty to express his opinions was hardly capable of exercising his proper role. Industrialism so affected the great mass of men that there was a serious question whether they had the qualities of wisdom and judgment necessary in choosing between competing policies and leaders.

Running counter to these baneful excesses of science and industrialism was the working-class movement. In England this movement gradually took the form of strong and cohesive trade unions with related cooperatives, friendly societies, and working-men's clubs. The working-class movements, not only in England but also in Europe and even in non-Western countries such as Japan and India, Lindsay regarded as the "most lively defenders of democracy." ${ }_{27}$ Unfortunately he did not regard this movement as sufficient. His major work, published during World War II, concluded with a predominantly pessimistic assessment of the "wisdom of the plain man." ${ }^{28}$ He expressed his sympathy for those notable critics of mass democracy, De Tocqueville and Ortega y Gasset, and promised a second volume to deal with the "problems of democratic controls." Totalitarianism threatened democracy from without and mobocracy from within.

In the postwar years Lindsay turned to an exposition of the "Philosophy of the British Labour Government." He admitted that nationalization made industry responsible to society but still felt that oligarchic relationships persisted within industry. A hierarchy was present in which a relatively few managed the work of many. Democratic socialism overcame the economic evils of industrialism and partially resolved the problem of power in bringing industry under society's control. Nonetheless, Lindsay thought a true Christian community of participants in the common life was lacking and the language of democracy in speaking of consent and the will of the people was "mythical." 29 In the end he seemed to see the democratic socialist society of postwar England as a political system that paid homage to democratic ideals but did not actually realize them.

Lindsay's theorizing ends with this somewhat bleak reference to democracy as "myth" and without the promised full treatment of democratic controls. No wonder reviewers of the earlier work reached discrepant conclusions, though each states a partial truth. Lindsay was, as Barker described him, a Puritan prophet in the sense that he did have a deeply historical outlook that saw men's destiny in modern times worked out in the contending individualisms of science and Christianity. Far more than most moderns, he did, as Elliott noted, develop a theory on classic lines that traced the relation of democracy to the Industrial Revolution and the growth of nationalism. More than David Easton allows, Lindsay's theory bears on contempo-

${ }^{27} M D S$, p. 192.

${ }^{23}$ Ibid., pp. $280 \mathrm{ff}$.

${ }^{29}$ See Ebenstein's Great Political Thinkers, pp. 803-7. Of course Lindsay has been neither first nor alone in using the term "myth." See Ben Halpern, " 'Myth' and 'Ideology' in Modern Usage," History and Theory, 1 (1961), 129-49. C. W. Cassinelli, in his analysis of the principal features of democratic states, devotes a chapter to myths as "indispensable oversimplifications." See his The Politics of Freedom (Seattle: University of Washington Press, 1961), chap. 7. 
rary problems of democracy and is not simply historical. ${ }^{30}$ Most pertinent of all was the anonymous reviewer who thought Lindsay's unfinished theory bore some comparison with earlier aristocratic regimes in which mass participation was lacking. Certainly Lindsay did not accept the eighteenth-century solution, but his difficulties in treating democratic controls lent itself to this criticism.

Above all, however, one should recognize that Lindsay's theory is fully and even poignantly modern in its treatment of power. His fundamental concern is with power as evidenced in the excessive influence of science and technology. He saw the threat as one both within and without the democratic system in the form of collective aggregates of power created by modern conditions. Laski was absolutely right in saying that Lindsay, a fellow socialist, neglected the problem of property relationships. To the idealist, the basic social division was not one between "the rich and the poor" but between "those who manage and control ... and those who are managed and controlled. .. ." ${ }^{31}$ Like Hegel, the twentieth-century Englishman profoundly suspected the acquisitive society and wanted state control. But the main point for both idealists was to assert a moral or spiritual control of society rather than a concern with a specific form of economic system. Much more than Hegel, Lindsay wanted to democratize the control by the state. Or, in broader terms, he wanted modern man's enormous powers subordinated to a moral ideal in a community of genuine fellowship. Yet like so many moderns, Lindsay thought man's technical ability to do things outran his moral capacities. The powers man created also threatened to destroy man for lack of effective moral guidance and restraint. There is an undertone of pathos and potential tragedy that well forebodes the arms race of the cold war and its frightening weapons. The problem of democratic controls was of a piece with this outlook. And although his postwar writings seemed less pessimistic, his final description of democratic socialism as in the utopian or "myth" stage of development pointed up his dilemma and continuing doubts.

Lindsay faced a serious problem and his doubts about the future of democracy are similar to those of a whole school of latter-day critics of mass democracy, industrialism, and urbanism. ${ }^{32}$ Still, for all the support one might muster for Lindsay's views, there is another side, too. From a variety of sources one can gather evidence that the strains of modern society do not appear, on close examination, to be so devastating as to overthrow democracy from within. And in some respects there is reason to believe that moderns have more freedom today than ever before. A second line of criticism will question Lindsay's norms of a democratic system. For the reali-

${ }^{30}$ References to Lindsay crop up here and there in contemporary literature. Though brief, these references do illustrate the point that he is both read and applied to contemporary problems. A partial list might include: Robert E. Lane, Political Life (Glencoe: Free Press, 1959), p. 345; H. Mark Roelof, The Tension of Citizenship (New York: Rinehart, 1957), pp. xvff; Neal Riemer, The Revival of Democratic Theory (New York: AppletonCentury Crofts, 1962), p. 71; Cassinelli, op. cit., p. 94, n. 13. In W. H. Chambers and R. H. Salisbury (eds.), Democracy in Mid-Twentieth Century (St. Louis: Washington University Press, 1960), Leon D. Epstein cites Lindsay's position specifically as an "orthodox contemporary answer" to the problems of public control of foreign policy (p. 133).

${ }^{31} M D S$, p. 184.

32 Daniel Bell, in The End of Ideology (Glencoe: Free Press, 1960), presents a classification of the various types of critics of mass society (p. 27). Winston White in Beyond Conformity (Glencoe: Free Press, 1961), discusses and classifies American commentators on the trends toward loss of individualism and surrender to conformity. 
ties of large-scale and impersonal societies strongly urge the view that the kind of cohesive, participant, and "comradely" system Lindsay preferred is quite unworkable. Whatever alternative democratic norms may be thought feasible, it can be argued that Lindsay's democratic system is not. As explained earlier, this testing can not be conclusive but can raise questions as to Lindsay's assumptions and inferences and point to new directions in which it would appear to be more profitable in the age of "the new society" to develop democratic theory.

In turning to criticism, then, one might first question Lindsay's misgivings as to industrialization. In the world of the 1960's it would seem that people everywhere want to industrialize. In the still tradition-dominated societies where the stress of change is likely to be greatest and misgivings most justified, the main question seems to be not if but only how fast and in what manner industrialization can proceed. Much of this impulse to change is well summarized by C. P. Snow in explaining what he considers the "primary gains" of the Industrial Revolution: "Enough to eat. . . Everyone able to read and write because an industrial society won't work without. Health, food, education, nothing but the industrial revolution could have spread them right down to the very poor." 33 At the other end of the world scale of industrial development, the nations of North America and much of Western Europe have been described as "affluent societies." In these societies the "good life" in a material sense is increasingly available to large numbers of the population. If these summary generalizations be true one can say of much of the modern attitude toward industrialization that those who have it are thought of as "affluent" and those who lack it want to industrialize to gain similar benefits. Lindsay himself recognized important material gains brought on by industrialization but on balance regarded it with suspicion. ${ }^{34}$ According to Adam Ulam, the prejudice that Lindsay shares with other idealists is such that "the philosophy of idealism does not escape the nostalgic note of a certain resentment against the industrial society where bigness and purely technical accomplishment can become conditions of survival." ${ }^{35}$ Industrialization and the desire for its material benefits in Lindsay's scale of values were decidedly on the lesser, grubby side of life.

That the process need not be as politically unpleasant as the idealist was apt to think is partially borne out by the investigations of two American sociologists, William Kornhauser and S. M. Lipset. Kornhauser has examined the effects of mass democracy, industrialization, and urbanism and concludes that these pervasive changes need not in themselves cause discontinuities and extremist movements. ${ }^{36}$ Where these changes occur slowly and the community has time to adjust to them the system is not permanently unsettled. The changes acquire "legitimacy" and are accepted to become a feature of an altered but stable system. Where changes take place rapidly and cause serious discontinuities in the social fabric and political system, then extremist movements acquire strength and totalitarianism becomes a threat.

\footnotetext{
${ }^{23}$ The Two Cultures and the Scientific Revolution (Cambridge: Cambridge University Press, 1960), p. 26.

${ }^{34} M D S$, chap. 7.

${ }^{35}$ Ulam, op. cit., p. 119.

${ }^{*}$ The Politics of Mass Society (Glencoe: Free Press, 1959), pp. 173-74.
} 
S. M. Lipset reached similar conclusions from similar evidence. He has written: "Wherever industrialization occurred rapidly, introducing sharp discontinuities between the pre-industrial and industrial situation, more rather than less extremist working-class movements emerged." ${ }^{37}$ If the system can accommodate itself to new demands, such as workers' legislation, and at the same time preserve a sense of legitimacy among conservatives, then a stable transition may occur. The point is that profound changes, such as industrialization and the emergence of the working class politically, can occur and have occurred, to become accepted as part of the system. And he notes "the absurd fact that ten out of the twelve stable European and English-speaking democracies are monarchies." Conservatives by and large become reconciled to much of modern political and social equality and the disagreement that remains poses no basic threat to the system. From this evidence there is reason to question Lindsay's sweeping tendency to link industrial change with an antidemocratic political propensity. There may and have been such linkages but by no means necessarily. In particular it is difficult to look upon the prosperous and increasingly united Europe of the 1960's as rent by the excesses of industrialism.

Pushing this point further there is the commonly noted fact that, contrary to Marx's predictions, the most highly industrialized countries have proved most resistant to the Marxist socialism and its twentieth-century concomitant of Communist control. The stresses and strains of industrialism pose their own problems and may bring conservative opposition as the industrial benefits are spread by measures to foster political and social equality. Yet not to develop a society's economic base, of which industrialism is today the main form, leaves the system vulnerable to revolution from the left. C. W. Cassinelli elaborates this position by arguing not only that democracy rests on the foundation of a "Middle Class society." He also argues that democracies in their nature follow social welfare policies. He maintains this feature arises from the dynamics of the electoral process that are distinctive to representative systems and not shared with other nondemocratic systems. ${ }^{38}$ Although this position itself raises questions that require a fuller analysis than Cassinelli offers, it illustrates an attitude different from Lindsay's spiritualized conception of socialism. Lindsay's "spiritualized" and almost religious socialism could not but look with some foreboding at the heavy stress placed on industrialism and its associated material benefits in twentieth-century societies.

A further major criticism of Lindsay's interpretation of industrialism is his view of the plight of the "plain man" in urban, industrial societies. Even granting the saving influences of the worker's movement to check the excesses of a "scientific individualism," Lindsay did not regard the ordinary man's lot as an attractive one. Like other critics of mass society he inclined to see this "plain man" as tending to be alienated and anomic within the pyramidal hierarchies of state and industrial system.

There is here, too, some evidence to the contrary. One important piece of evidence is from Key's analysis of American public opinion and "Morale in the Industrial Order." According to Key, "Remarkably little variation existed in the outlook of different occupational groups. ... Prospects for getting ahead looked less

\footnotetext{
${ }^{87}$ Political Man, p. 68. Emphasis in original.

${ }^{28}$ Cassinelli, op. cit., chap. 3.
} 
rosy to the unskilled worker than to the businessman; yet few of either group were so gloomy as to see no opportunity for the average man." 39 A poll in 1956 by the Michigan Center adds to the evidence. Key remarks that although 50 per cent of the unskilled workers expected their situation to stay the same, "the data suggest the presence of fairly widespread satisfaction. . . " Another piece of evidence comes from Scott Greer's survey of a number of studies of American city-dwellers. He concluded that the life of these urbanites was not ideal but that "the picture is less frightening than that of the atomistic man adrift in mass society, anomic and destructive." 40 The American urbanite is not the perfect citizen, but most achieve a tolerable adjustment that keeps them from being alienated. A recent addition to the evidence is the report of a poll by George Gallup in the summer of 1962. When his pollsters asked people whether they thought "life for people generally will get better - or will get worse?" there were 55 per cent willing to say life would get better and only 23 per cent to affirm that it would get worse. ${ }^{41}$ In part this poll reflected a shortterm movement since the Korean War when the replies were less optimistic; but neither this poll nor the other evidence cited goes far to prove that the modern American is in the condition Lindsay pictured for the "plain man." There are strains and frustrations but most Americans do not appear to be dangerously dissatisfied and alienated.

Closely linked with the question of alienation is that as to the freedom of the ordinary man. For Lindsay, as for the other critics of mass society, highly industrialized and urbanized systems tend in a variety of ways to foster conformity and frustration of opportunities for personal development. In contrast to this point of view there are a number of observers who argue that freedom is not lost and is even in some ways expanded. John Roche has argued this case in an examination of the "American tradition of freedom." In the old days of pre-industrial America, freedom was, he maintains, a by-product of separation and isolation. Today, by contrast, freedom has become a conscious national goal protected in a variety of ways. The anonymity of large urban centers protects the individual from prying and interference in a cloak of indifference. Further, the law profession today in courts, government, and private practice is much more aware of the importance of the protections embodied in due process. And there are civic groups, such as the American Givil Liberties Union, which do yoeman's work in safeguarding individual rights. He sums up his case by writing: "To put it a little too neatly, in rural America, freedom was a function of openness, of the individual's ability to get out of an oppressive environment; in urban America, freedom is a function of impersonalization, of the growth of legal and political institutions which muffle interpersonal and intergroup conflicts." 42

${ }^{29}$ V. O. Key, Jr., Public Opinion and American Democracy (New York: Knopf, 1961), pp. 127-30. For related evidence on the U.S. - and elsewhere - see the UNESCO survey taken in 1948 and published by William Buchanan and Hadley Cantril, How Nations See Each Other (Urbana: University of Illinois Press, 1953).

${ }^{40}$ Scott Greer, "Individual Participation in Mass Society," in Roland Young (ed.), Approaches to the Study of Politics (Evanston: Northwestern University Press, 1958), p. 342.

${ }^{41}$ Houston Post, August 30, 1962, p. 8, section 5.

"John Roche, "American Liberty: An Examination of the Tradition of Freedom," in Milton Konvitz and Clinton Rossiter (eds.), Aspects of Liberty (Ithaca: Cornell University Press, 1958), p. 151. 
Supplementing this line of argument is evidence from a volume of essays reevaluating the ideas of David Riesman on conformity in present-day America. In one of the critiques, S. M. Lipset argues that American character has not changed much since De Tocqueville wrote. Long ago in De Tocqueville's time, Americans had a mobile, egalitarian, and status-conscious culture and have today as well. But there has also always been, and still is, Lipset argues, a competitive, achievementoriented system of values with many opportunities for individualism. According to Lipset, some of the very characteristics that contribute to other-directedness and conformity, such as urbanism and bureaucratization in a fluid, mobile society, may also nourish a hard-driving competitive ethic and provide avenues for the exercise of choice not present earlier. ${ }^{43}$ Among these he cites the decline of family firms and the growth of bureaucracies within which advancement depends more on performance than on having the right friends and relations. The area of arbitrary whim is reduced by the bureaucracy and its restraints, and an ethos of hard work is spread among "non-owners" who may now advance in accord with performance. Additionally, and like Roche, Lipset also believes that with the growth of cities there has been a decline in the small-town and rural-area type of life with their comparatively rigid status systems and narrow round of existence. In urban life, on the other hand, relations are more impersonal and for this reason conformity may be more "outward" and less "inward." On this last Lipset quotes Clyde Kluckhohn's assessment: "If one accepts outwardly the conventions of one's group, one may have greater psychic energy to develop and fulfill one's private potentialities as a unique person. I have encountered no substantial evidence that this 'conformity' is thorough-goingly "inward." "44 And Lipset adds, "As status seeking is the by-product of strong equalitarianism, so conformity may permit, or even demand, inner autonomy."

Even Riesman seems willing to modify his position a bit. In a reconsideration of "autonomy" he discards leisure as a creative personalized focus for energies stifled by work and confesses that he minimized the objective pressures making work harder for the profesional and managerial strata while the hours of work were reduced and grim conditions were being mitigated for lower-status occupations. Most importantly, Riesman now appears willing to look more favorably than before upon the prospects for an increase in autonomy. Thus, "the loss of older fixed boundaries of class, caste, and nation does not inevitably mean a growing sameness in the world in terms of the development of personal styles of life." The decline of the old barriers of nation and class may permit new forms of association that could foster variety and differences. Riesman is far from optimistic but appears more hopeful than in the past. ${ }^{45}$

${ }^{43}$ S. M. Lipset, "A Changing American Character?" in S. M. Lipset and Leo Lowenthal (eds.), Culture and Social Character: The Work of David Riesman Revisited (Glencoe: Free Press, 1961), pp. 166ff.

${ }^{44}$ See also Clyde Kluckhohn's review article, "Shifts in American Values," World Politics, 11 (1959), 250-61. Daniel Lerner attacks the critics of mass society and the organization man by speculating on the historical evolution of an "empathetic personality" that is functionally necessary to a physically and socially mobile society. See his "Comfort and Fun: Morality in a Nice Society," American Scholar (Spring 1958), pp. 153-65. See also Winston White, Beyond Conformity, chaps. 6, 7, and 8 on "An Alternative View."

ws "The Lonely Crowd: A Reconsideration in 1960," in Lipset and Lowenthal, op. cit., pp. $456-58$. 
Of course these remarks do not mean that the modern American or European leads an ideal existence. The evidence suggests hopeful trends but is certainly incomplete. In the end, the most balanced assessment to set against Lindsay and other critics of mass society would be that of De Tocqueville. For all of the latter's criticism of the course of early American democracy, he saw benefits too. Some forms of individualism, particularly that enjoyed by the aristocrat in nineteenth-century Europe, had declined then as later. And unquestionably the "freedom from" enjoyed by the upper-class European and probably also by his counterpart in America must have been remarkable in the days before the welfare state imposed its burdens and restraints. But as De Tocqueville also noted in recording this loss, there was a great gain for the mass of men. A state of equality was "less elevated ... but more just." 46 With the further advance of social and political equality brought by mid-twentieth century, the "plain man" of much of Western society has achieved large-scale benefits. The spread of education, the rise of incomes, the reduction of working hours and the choice of activities for work and recreation made available on a mass scale in urban, industrial societies all have conjoined to spread remarkable benefits in the mass democracies. In these circumstances De Tocqueville - and Lindsay - are right in seeing some loss of a "freedom from" for those who were advantageously placed in nineteenth-century societies. But De Tocqueville, more than Lindsay, was willing to recognize the gains for the mass of men, gains much more evident in the middle of the twentieth century. This balancing of the scales by one whom Lindsay himself cited is perhaps the best reply possible to the Englishman's picture of the plight of the "plain man."

A last commentary on Lindsay's attitude toward industralism and the changes it has wrought pertains to the relative weight to be assigned to the internal dangers from this quarter. It is true that his wide-ranging philosophy dealt with the dangers of nationalism and the totalitarian powers, both fascist and communist. But the over-all effect was to give little attention to the distinctive problems of the international arena. And it is here that the "excesses" of science in creating terrible new weapons of war are most evident. For Lindsay, the entire international sector was compressed and reduced largely to a manifestation of the dangers of a selfish individualism. The resulting political philosophy was one-sided. As Adam Ulam remarks, Lindsay "reproduces unconsciously the frame of mind which was a legacy from the days of England's undoubted supremacy in the world. ..." ${ }^{47}$ When England's position changed to become more precarious, Lindsay's thought was still focused chiefly on internal problems or saw international turmoil as largely a further form of internal social stress.

Apart from Lindsay's attitude toward industrialism there is another category of possible criticisms that pertains to Lindsay's idealized version of the prevailing spirit of a democracy. His original ideal of democracy went back to the days prior to the Industrial Revolution when the early Puritans developed their democratic practices and "the simple agricultural society . . . in countries like Switzerland or

\footnotetext{
${ }^{18}$ Democracy in America, "The World's Classics," ed. and with intro. by Henry Steele Commager (London: Oxford University Press, 1952), p. 597.

${ }^{47}$ Op. cit., p. 119.
} 
Norway or New England made democracy an obvious form of government." 48 In these small, cohesive societies, participation presented no overwhelming problems. It is true that Lindsay sought to emphasize not so much the actual counting of heads but rather the participation of each in an accepted sense of common will and purpose. At its best democracy certainly did not mean the clamorous assembly with each taking part equally. It is also true that he saw some distinctive problems created by the sheer size of modern systems; he recognized full well the need for an elite, cast doubt upon the wisdom of the plain man, and stressed the problem of size in modern democracies. Still, he seemed to think in terms of some manner of highly personal and unique kind of participation. For this reason he saw the need to revise his model of democracy based on the early Puritans and turned first to Rousseau but above all to Bosanquet. In the latter he thought he found a conception of the spirit of democratic participation adaptable to the nation-state. He wanted the "spirit of the common life" to be the "sovereign principle" to guide legislation and have authority over the individual. He wanted in politics a spirit Adam Ulam describes as a "religious, semi-mystic one: the citizens of modern democracy need to be inoculated by what they [Lindsay and other Labour party theorists] call the common life." 40 Against this ideal one must set the realities of mass participation. The argument will be that his ideal of twentieth-century democracy retained the flavor of a small, cohesive, participating community that is quite unrealistic today.

To begin with, there is the evidence from electoral studies. The well-known study of "The Political Activity of American Citizens" by Woodward and Roper concluded in 1950 that only one-quarter of the adult population could be considered "active" and the other three-quarters "inactive" or "very inactive." 50 More recently, that comprehensive study of American electoral behavior, The American Voter, found the theme to which its authors must return repeatedly to be "the low emotional involvement of the electorate in politics, its slight awareness of public affairs, its failure to think in structured ideological terms; and its pervasive sense of attachment to one or the other of two major parties." ${ }_{51}$ Nor do other voting studies find substantial disagreement. The American public is not much involved politically and the ordinary voter is not likely to give much attention to politics so as to know the issues and candidates well.

Supplementing these studies of electoral behavior are those on public opinion. V. O. Key's assessment of American public opinion casts serious doubt on the conception of an ideological consensus underlying the political system: "Whatever the characteristics of popular attitude that permit governments to operate as if a basic consensus existed, they do not seem to consist of ideas that amount to a consensus on political fundamentals unless we mean by that phrase nothing more than a popular recognition of the legitimacy of the regime." 52 Nor is there a "majority will" that can be said to characterize the great mass of the population on specific issues of the

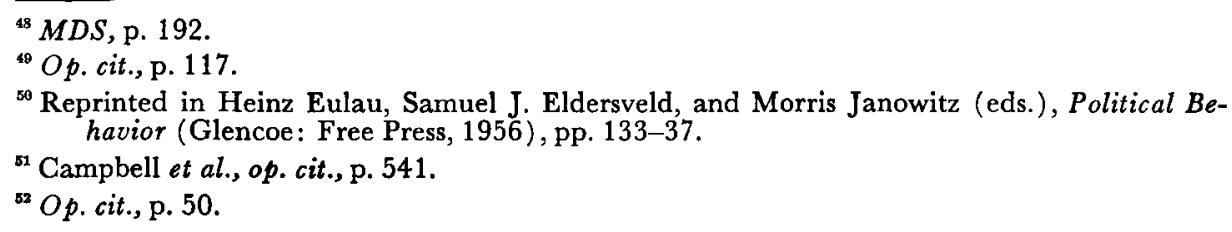


day. Instead, Key believes there is a "concentration" of opinion in an "attentive public" that is probably no more than one-fifth of the electorate and on many issues apt to be less. ${ }^{53}$ Most of the public at large seems to lack a sense of agreed ideology underlying the system and to be unconcerned with most of the political issues of the day that the attentive group does heed. In a very real sense public opinion is the opinion of a minority.

Apart from politics, what of participation in other kinds of organized social life? Americans have a reputation as "joiners" and there are numberless associations of all kinds throughout the American scene. Bernard Barber has taken a long look at this reputation and concludes that the reality is one of limited participation. He finds there are countless associations but that most people belong to none and that the associations themselves are run by a small number of actives. Mass participation does not exist. ${ }^{54}$ Seymour Lipset reaches a similar conclusion from his study of trade unions. He concludes that the requirements of the organization foster bureaucracy with an entrenched leadership or oligarchy. He sums up with this claim: "The obvious conclusions of this analysis are that the functional requirements for democracy cannot be met most of the time in most unions." 55

Beyond these inquiries there is Scott Greer's previously cited study of the American urbanite, which specifically concludes that the lives of these people are "privitized." They do not feel alienated and adrift but they fail to participate in the life of society. Their round of existence is bounded chiefly by family and relatives and most of them participate little, or not at all, in politics, occupational associations, or even in social and recreational organizations. ${ }^{56}$ For most Americans, life is lived pretty much in the home and closely related activities. From this data one is likely to conclude that American society appears to have a secular, atomized quality consisting of privitized individuals living largely within the bounds of primary groups. The contrast with Lindsay's notion of a community mystically united in a sense of "common life" is notable. And it would seem that his democratic norm of participation, albeit spiritual more than physical, is in the end quite unrealistic. An ideal drawn originally from much simpler and smaller societies hardly suits the size and impersonality of nation-states. To try to apply such an ideal in these circumstances is apt to lead to the conclusion that democracy is a myth. ${ }^{57}$

This review of a Puritan prophet's theory of democracy has sought, first, to explain the key ambiguity in his theory that led to the reviewer's mixed conclusions and, secondly, to re-evaluate his norms of democracy in light of some recent empiri-

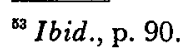

"54 "Participation and Mass Apathy in Associations" in A. W. Gouldner (ed.), Studies in Leadership (New York: Harper, 1950), pp. 481ff. Similarly, E. E. Schattschneider reviews the literature on pressure groups to conclude that they are limited so as to have a strong upper class bias and ends with an estimate that "Probably about 90 per cent of the people cannot get into the pressure system." See The Semi-Sovereign People (New York: Holt, Rinehart, and Winston, 1960), p. 35.

${ }^{55}$ Political Man, p. 394.

${ }^{56}$ Greer, loc. cit., pp. 331-32.

${ }^{57}$ E. E. Schattschneider has put it beautifully: "We become cynical about democracy because the public does not act the way the simplistic theory of democracy says it should act, or we try to whip the public into doing things it does not want to do, is unable to do and has too much sense to do. The crisis here is not a crisis in democracy but a crisis in theory." Op. cit., p. 134 .
} 
cal findings. It has been argued that the ambiguity in Lindsay's theory arose from the failure to complete the spelling out of democratic controls. He was unable to do so because his idealism distorted his outlook in two respects. For one, it contributed to a deeply critical conception of the impact of science and industrialism and its effect on the "plain man" upon whom democratic controls must ultimately rely. Secondly, his idealism was instrumental in forming a norm of democratic community life that is at odds with secular, impersonal, and large-scale nation-states of the twentieth century. Admittedly, the evidence cited cannot afford any final proofs. But this criticism can suggest that the assumptions about the modern world and the norms of democratic thought expressed by Lindsay are questionable and require revision to meet modern conditions. The "new society" of the twentieth century does not seem to fit the operative ideals of the modern democratic state laid down by Lindsay.

In finally evaluating Lindsay's theory one can well admire his attempt to link history and political theory in a prophetic vision of man's moral control over the changing and turbulent environment of modern times. His theory does convey a real sense of the widely felt discrepancy between man's ideals and moral practice, on the one hand, and the growing technological powers, on the other. Man has transformed his world and continues to increase his material powers, even to the point of possible self-destruction. And to criticize Lindsay on the problems of community life in an industrial age is not to deny all significance to these issues. There are, indeed, serious problems of human adjustment present in coping with the stresses of industrial society. On these points the idealism strengthens the theory and gives force to his statement of the challenges of today. Unfortunately, Lindsay carried this idealism to an unrealistic extent in leaning heavily on an idealized past and in expressing a fundamental distaste for some of the most characteristic trends of modern times, with a consequent neglect of the threats arising from the international sector. The restatement of the operative ideals of democracy must begin with a realistic accommodation to things about the modern world Lindsay could not altogether accept. As E. H. Carr has written of the transition from individualism to mass democracy and the new society, one must look "to the shore ahead," not the "ruins behind." 